\title{
Platform Inequality: Gender in the Gig-Economy
}

\author{
Arianne Renan Barzilay* $\mathcal{E}^{\circ}$ Anat Ben-David
}

Americans are making extra money renting out a spare room, designing websites, selling products they design themselves at home, or even driving their own car. This 'on demand' or so-called 'gig economy' is creating exciting opportunities and unleashing innovation but it's also raising hard questions about workplace protections and what a good job will look like in the future.

-Hillary Rodham Clinton ${ }^{1}$

\begin{abstract}
Laboring in the new economy has recently drawn tremendous social, legal, and political debate. The changes created by platform-facilitated labor are considered fundamental challenges to the future of work and are generating contestation regarding the proper classification of laborers as employees or independent contractors. Yet, despite this growing debate, attention to gender dimensions of such laboring is currently lacking. This Article considers the gendered promises and challenges that are associated with platform-facilitated labor, and provides an innovative empirical analysis of gender discrepancies in such labor; it conducts a case study of platform-facilitated labor using

* Assistant Professor, University of Haifa Faculty of Law.

${ }^{+}$Senior Lecturer, Department of Sociology, Political Science and Communication, the Open University of Israel.

We are grateful to Einat Albin, Naomi Cahn, June Carbone, Jessica Clarke, Efrat Daskal, Guy Davidov, Yossi Dahan, Debbie Dinner, Eldar Haber, Dafna Hacker, Yoram Kalman, Laura Kessler, Shelly Kreiczer-Levy, Lilach Lurie, Faina Milman-Sivan, Sagit Mor, Guy Mundlak, Orna Rabinovich-Einy, Amnon Riechman, Noya Rimalt, Betsy Rosenblatt, Sharon Shakargy, Adam Shinar, and Oren Soffer for helpful suggestions and valuable feedback, and to Niva Elkin-Koren for her generous support of this research project. Thanks to Adam Amram for programming and data analysis assistance and to Ido Porat and Ofer Toledano for research assistance. Thanks to Benjamin Heller, Beata Safari, Christopher Mazza and the editors of the Seton Hall Law Review for wonderful editorial assistance. This research was supported by the I-CORE Program of the Planning and Budgeting Committee and The Israel Science Foundation (1716/12).

1 Christina Reynolds, Reality Check: Hillary Clinton and the Sharing Economy, HiLLARYCLINTON.COM, https://www.hillaryclinton.com/briefing/updates/2015/07/16/reality-checksharing-economy (last visited Dec. 17, 2016).
\end{abstract}


computational methods that capture some of the gendered interactions hosted by a digital platform. These empirical findings demonstrate that although women work for more hours on the platform, women's average hourly rates are significantly lower than men's, averaging about 2/3 (two-thirds) of men's rates. Such gaps in hourly rates persist even after controlling for feedback score, experience, occupational category, hours of work, and educational attainment. These findings suggest we are witnessing the remaking of women into devalued workers. They point to the new ways in which sex inequality is occurring in platform-facilitated labor. They suggest that we are beholding a third generation of sex inequality, termed "Discrimination 3.0," in which discrimination is no longer merely a function of formal barriers or even implicit biases. The Article sketches Equality-by-Design (EbD) as a possible direction for future redress, through the enlisting of platform technology to enhance gender parity. In sum, this Article provides an empirical base and analysis for understanding the new ways sex inequality is taking hold in platform-facilitated labor.

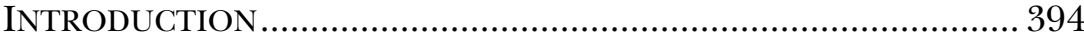

I. OPPORTUNITIES AND CHALLENGES OF BALKANIZED LABOR .... 399

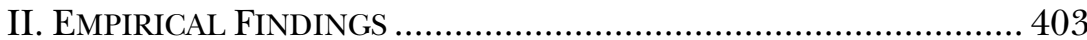

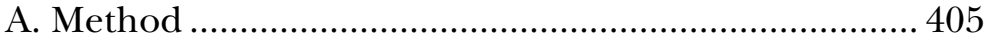

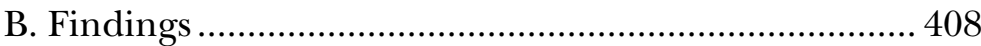

C. Discussion of Findings ............................................... 420

PART III. THE INEPTITUDE OF GURRENT LEGAL NORMS ............. 422

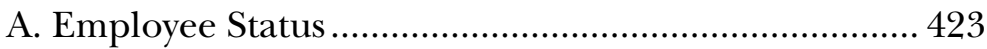

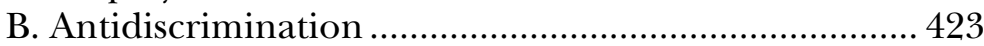

PART IV. FROM DISCRIMINATION 3.0 TOWARDS EQUALITY-BY-DESIGN

.

A. A Third Generation of Discrimination ...................... 427

B. Towards A Platform for Equality? .............................. 429

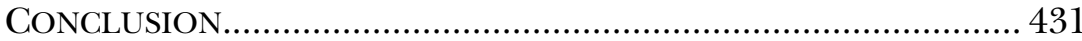

\section{INTRODUCTION}

Flexibilization, globalization and privatization have presented challenges for employment law for some time now. ${ }^{2}$ Sociologists and legal scholars have documented and critiqued the precarious nature

2 See generally Katherine V.W. Stone, Flexibilization, Globalization and Privatization: Three Challenges to Labour Rights in Our Time, 44 Osgoode HaLl L.J. 77, 77 (2006) (noting that Flexibilization "refers to the changing work practices by which firms no longer use internal labour markets or implicitly promise employees lifetime job security, but rather seek flexible employment relations that permit them to increase or diminish their workforce, and reassign and redeploy employees with ease”). 
and gendered implications of the work these forces have created. ${ }^{3}$ We know that precarious work-work that departs from the model of a full-time, year-round employment relationship with a single employer-has historically been conducted mostly by women. ${ }^{4}$ In the past few years, however, precarious work has expanded in magnitude, scope, and trendiness for both men and women, professionals and non-professionals. ${ }^{5}$ With the rise of the "sharing" economy, new companies are using technology to initiate connections between workers offering ad hoc labor and third parties in need of tasks performed. ${ }^{6}$ The "sharing" or "gig" economy is generating widespread conversation among academics, lawyers, and policy makers, ${ }^{7}$ even

3 Precarious work, characterized by low wages and the absence of job security, is associated with part time employment, temp work, on-call work, home working, and telecommuting. Katherine V.W. Stone, From Widgets to Digits: Employment Regulation FOR the ChANGing WORKPLACE 69-86 (2004); Judy Fudge \& Rosemary Owens, Precarious Work, Women, and the New Economy: The Challenge to Legal Norms, in Precarious WORK, WOMEN, AND THE NEW ECONOMY: THE CHALlENGES TO LEgAL NORMS 3, 8, 12-13 (Judy Fudge \& Rosemary Owens eds., 2006) (noting that this work is performed largely by women). See generally Erin HatTon, The Temp Economy: From Kelly GiRls to Permatemps IN POSTWAR America (2011) (illustrating how the temp industry transformed work in America). For the effects of economic inequality on families, see generally June Carbone \& NAOMI R. CAHn, Marriage Markets: How INEQUALITY IS REMAKING THE AMERICAN FAMILY (2014).

Fudge \& Owens, supra note 3 , at 8 (noting that flexible forms of labor, casual labor, contract labor and outsourcing are associated primarily with women). For the historical development of women's labor, see generally ALICE KESSLER-HARRIS, OUT TO WORK: A History OF WAGE EARNING WOMEN IN THE UNITED STATES 30, 36 (2003) (noting part time and alternating jobs as historically common for women wage earners).

5 See Tamara Kneese et al., Understanding Fair Labor Practices in a Networked Age (Data \& Soc'y Research Inst. Working Paper, 2014), http:/ /www.datasociety.net/pubs /fow/FairLabor.pdf (indicating an increase in part-time, independent, contract, freelance modes of labor and noting the "coolness" of individual risk); Orly Lobel, The Gig Economy and the Future of Employment and Labor Law, U.S.F. L. REV. 2 (forthcoming), [hereinafter Lobel, The Gig Economy], https://papers.ssrn.com/sol3/papers.cfm? abstract_id=2848456 (discussing how new digital platform companies are disrupting established markets).

${ }^{6}$ See Matthew W. Finkin, Beclouded Work, Beclouded Workers in Historical Perspective, 37 COMP. LAB. L. \& POL'YJ. 603 (2016) (describing the gig economy, and placing it in historical perspective). See also Megan Carboni, A New Class of Worker for The Sharing Economy, 22 Rich.J.L. \& TECH. 1 (2016). See generally Kneese et al., supra note 5 (noting that technology is central to the sharing economy flexible work patterns that enable task-work and that websites connect individuals to customers who want specific tasks performed).

See Thomas E. Perez, Sec'y of Labor, Remarks at the Department of Labor Future of Work Symposium (Dec. 10, 2015), https://www.dol.gov/newsroom/ speech/20151210. See also Kneese et al., supra note 5; Benjamin Sachs, Uber: Employee Status and "Flexibility", ON LABOR (Sept. 25, 2015), https://onlabor.org/2015/09/25/uber-employee-status-and-flexibility; Noah Zatz, Is Uber Wagging the Dog With Its Moonlighting Drivers?, ON LABOR (Feb. 1, 2016), https:/ / onlabor.org/2016/02/01/is-uber-wagging-the-dog-with-its-moonlighting- 
permeating the recent presidential race, ${ }^{8}$ and is likely to growingly preoccupy law and policy in coming years. While there is no clear definition of this economy, for our purposes, the Article will characterize it by the disaggregation of consumption and the segmentation of production via online platforms. ${ }^{9}$ Indeed, fragmented, loose, informal, task-based forms of labor have been amplified worldwide. We now see micro-labor on a macro scale-so much so that some have claimed we are witnessing a "paradigmatic shift" in the way we work. ${ }^{10}$

"Sharing" economy companies, at first benignly dubbed "peer to peer" and marketed as fresh, innovative, and "collaborative," have mushroomed in popularity and scale. The "sharing" economy now provides a wide and ever-broadening range of services, from driving, to running errands, to professional tasks. ${ }^{12}$ While "sharing" economy firms vary somewhat in the amount of control they exert over laborers, their specific discursive terminology of laborers, ${ }^{13}$ the platforms they provide, and the fees they collect, they all: (a) use the Internet; and (b) endorse the ability of laborers to earn money, often from the vicinity of one's home and, importantly, on one's own schedule. These companies are increasingly criticized for ushering in with full force an "on-demand," "on-call," "gig"-based economy, and for selling us ubercapitalism under the guise of sharing rhetoric. ${ }^{14}$

drivers.

${ }^{8}$ See Reynolds, supra note 1.

9 See Daniel E. Rauch \& David Schleicher, Like Uber, But for Local Government Policy: The Future of Local Regulation of the "Sharing Economy" 8 (George Mason Univ. L. \& Econ. Research Paper Series, No. 15-01, 2015), http:/ papers.ssrn.com/sol3/papers.cfm? abstract_id=2549919 (explaining the disaggregation of consumption). For general fissured trends of employment, see also DAVID WEIL, THE FISSURED WORKPLACE: WHY Work Became So Bad for So Many And What Can Be Done to Improve It (2014).

${ }^{10}$ See Orly Lobel, The Law of the Platform, 101 MinN. L. Rev. 87 (2016). See also Mary L. Gray, Your Job Is About to Get 'Taskified', L.A. Times (Jan. 8, 2016, 6:52 PM), http:/ /www.latimes.com/opinion/op-ed/la-oe-0110-digital-turk-work-20160110story.html (instead of hiring employees, firms can now post tasks on the web thus fragmenting jobs; such "online piecework" represents a "radical shift in how we define employment itself").

11 Rachel Botsman \& Roo Rodgers, What's Mine Is Yours: The Rise of COLlaborative CONSUMPTION xiv-xv (2010)

12 Jeremias Prassl \& Martin Risaktt, Uber, Taskrabbit, and Co.: Platforms as Employers? Rethinking the Legal Analysis of Crowdwork, 37 COMP. LAB. L. \& POL'YJ. 619, 622 (2016).

13 For example, Uber calls its laborers drivers, "partners," and "independent contractors." See Partners, UbER.COM, https://partners.uber.com/join (last visited July 23, 2016). Taskrabbit calls its laborers "taskers." See TASkRABBiT, https://www.taskrabbit.com (last visited July 23, 2016). (2015). 
Technological advances and changes in social and economic organization often present moments of opportunity and challenge. ${ }^{15}$ Newly technologized contingent work practices are already creating tremendous social change. ${ }^{16}$ Increasingly, such work practices are remapping the frontier between home and work, public and private, employment and contracting. ${ }^{17}$ They are also testing the boundaries of legal responsibility. ${ }^{18}$ Employment law scholarship has begun to pay attention to this phenomenon, focusing primarily on whether taskers should be classified as employees or independent contractors. ${ }^{19}$ Still, little is known about the gender dimensions of platform-facilitated labor. ${ }^{20}$ We should start filling in this void and thinking through the gendered implications and legal ramifications of laboring in the new, "sharing" economy. This Article begins that process.

Part I considers the gendered promises and challenges associated with platform-facilitated labor. On its face, platform-facilitated labor has potential to enhance gender equality because laborers may sometimes enjoy a degree of anonymity and inclusiveness when offering work via platform, and a substantial degree of flexibility which

15 See Yochai Benkler, The Wealth of Networks: How Social Production TRANSFORMS MARKETS AND FREEDOM 2 (2006).

${ }_{16}$ Lobel, The Gig Economy, supra note 5, at 3.

17 See id. at 3-7; Naomi Schoenbaum, Gender and the Sharing Economy, FordHAM URBAN L.J. 1, 5 (forthcoming), https:/ / papers.ssrn.com/sol3/papers.cfm?abstract -id=2865710.

${ }^{18}$ See, e.g., Order-Denying-Plaintiffs-Motion-for-Preliminary Approval of Settlement, UNITED STATES DisTRICT CT., http:/ / www.cand.uscourts.gov/EMC/OConnorvUber Technologies (last visited Jan. 2, 2017) (Uber argues that because it sets minimal controls over drivers' hours, they are not Uber employees, thus testing the boundaries of its legal responsibilities).

19 See, e.g., Keith Cunningham-Parmeter, From Amazon to Uber: Defining Employment in the Modern Economy, 96 B.U. L. REv. 1637 (2016); Valerio De Stefano, The Rise of the "Just-in-Time Workforce": On-Demand Work, Crowd Work and Labor Protection in the "GigEconomy”, 37 Comp. LAB. L. \& PoL'y J. 471, 471 (2016); Veena Dubal, Wage Slave or Entrepreneur?: Contesting the Dualism of Legal Worker Identities, 105 CAL. L. REv. (forthcoming 2017), http://papers.ssrn.com/sol3/papers.cfm?abstract_id=2796728; Benjamin Means \& Joseph A. Seiner, Navigating the Uber Economy, 49 U.C. DAVIS L. REV. 1511, 1511 (2016); Brishen Rogers, Employment Rights in the Platform Economy: Getting Back to Basics, 10 Harv. L. \& Pol'y Rev. 479, 479 (2016). Brishen Rogers, The Social Costs of Uber, 82 U. Chi. L. Rev. Dialogue 85 (2015). See also Guy Davidov, The Status of Uber Drivers, ON LABOR (May 17, 2016), https://onlabor.org/2016/05/17/guest-post-thestatus-of-uber-drivers-part-1-some-preliminary-questions; Sachs, supra note 7 (considering whether flexibility enjoyed by workers can determine employee or independent contractor status).

${ }^{20}$ See Schoenbaum, supra note 17. Schoenbaum has claimed that the pervasiveness of intimacy in services such as those provided through Uber and Airbnb may prime sex stereotypes. On race and the sharing economy, see generally Nancy Leong, New Economy, Old Biases, 100 MinN. L. Rev. 2153, 2153 (2016). 
may be helpful for those with gendered familial responsibilities. ${ }^{21}$ On the other hand, such work may actually be hindering laborers, since it requires far less investment in workers, and offers fewer opportunities for workers to establish close relationships with work-providers. Moreover, at present such work provides a paucity of benefits for laborers, and a dearth of protections against discrimination.

While the promises and challenges posed to gender equality by this form of labor are considerable, there is an acute shortage of data analyzing online platform work from a gender perspective. Part II empirically examines how women are doing in this growing economy. Through an empirical case-study focusing on workers on one global platform ("the Platform"), it examines gender discrepancies in platform-facilitated online labor. The Article employs a computational approach that automatically extracts profile data from the Platform's Application Programming Interface (API). ${ }^{22}$ Rather than relying on answers or data reported by users through surveys, extracting data directly from the Platform's API enables us to capture a snapshot of the actual user profiles that are in use on the Platform. The application of computational, unobtrusive methods is tailored to capture the unique digital aspects of the "gig" economy by providing a snapshot of the actual digital interactions that the Platform hosts, as they are shaped by its technological affordances, and as they are made available through the Platform's API. The study analyzes over 4,600 online taskers' requested rates, occupations, and work-hours. Using statistical analysis, its findings illustrate a dramatic gender gap in the hourly rate requested by men and women who are seeking work through the studied platform. The findings show women's average hourly requested rates are $37 \%$ lower than men's. Such gaps in hourly requested rates persist even after controlling for feedback score, experience, occupational category, hours of work, and educational attainment. Surprisingly, among the different occupational categories available on the Platform, the most pervasive gender gaps were found with regard to those offering legal services.

${ }^{21}$ Lack of anonymity has been suggested to prime sex stereotypes, see Schoenbaum, supra note 17. Flexibility may prove helpful for those with caring responsibilities. JOAN C. WILliams, UNBENDING GENDER: WHY FAMILY AND WORK CONFLict AND WHAT TO Do ABOUT IT 84-86(2000). Family care still tends to be gendered. See Naomi R. Cahn, The Power of Caretaking, 12 Yale J.L. \& Feminism 177, 188 (2000).

${ }^{22}$ Permission to extract the data was obtained through the Platform. See E-mail from API Support Team, to Adam Amram (Mar. 3, 2016, 9:25 AM) (on file with authors). For more on the data collection and for the benefits and limitations of this kind of methodological approach, see infra Part II. 
Given these dramatic empirical findings, Part III begins to consider the legal implications for working in platform-facilitated online labor. It argues that to realize the promises of platformfacilitated labor for gender equality we must: (a) make such labor a sustainable work option for those heavily involved; and (b) mitigate the perils faced disproportionately by women. It posits the ineptitude of current legal norms to do both. Part IV suggests that we are witnessing a third generation of sex-inequality, which we term "Discrimination 3.0" in which sex discrimination may be occurring on platforms, and in which platforms may (likely unconsciously) be harboring gender inequality. It illuminates challenges that platform inequality poses for antidiscrimination law more generally, and calls for contemplating new mechanisms for promoting work equality. It suggests that we could use platform technology itself to promote Equality-By-Design (EbD) as a mechanism towards enhancing gender parity in platform-facilitated labor.

\section{OPPORTUNITIES AND CHALLENGES OF BALKANIZED LABOR}

The "sharing" economy has been celebrated as a job creator, a liberating option for those unable to attain stable employment, and as providing freedom and flexibility. ${ }^{23}$ By some estimates, more than $22 \%$ of U.S. adults (approximately 45 million people) have already offered their labor and services in the "sharing" economy, ${ }^{24}$ with numbers likely to grow. ${ }^{25}$ This Part outlines promises and pitfalls associated with this

\footnotetext{
23 See Natasha Singer, In the Sharing Economy, Workers Find Both Freedom and Uncertainty, N.Y. Times (Aug. 16, 2014), http://www.nytimes.com/2014/08/17/ technology/in-the-sharing-economy-workers-find-both-freedom-and-uncertainty. html. See also Paul Merrion \& Fareeha Ali, Making Inroads: Women Cabbies on the Rise, CHI. Bus. (Sept. 27, 2014), http://www.chicagobusiness.com/article/20140927/ISSU E01/309279976/making-inroads-women-cabbies-on-the-rise.

${ }_{24}$ Katy Steinmetz, Exclusive: See How Big the Gig Economy Really Is, Time (Jan. 6, 2016), http://time.com/4169532/sharing-economy-poll. But other estimates found that only 4 percent of the adult population had ever participated in the online platform economy. Paychecks, Paydays, and the Online Platform Economy: Big Data on Income Volatility, JPMORGAN CHASE \& Co. 8-9, 21 (Feb. 2016), https://www.jpmorganchase.com/corporate/institute/document/jpmc-institutevolatility-2-report.pdf. Other research suggests workers on online-platforms comprise a small but rapidly growing share of the economy. Lawrence F. Katz \& Alan B. Krueger, The Rise and Nature of Alternative Work Arrangements in the United States, 1995-2015, SCHOLARS AT HARVARD (2016), http://scholar.harvard.edu/files/lkatz/files/katz krueger_cws_v3.pdf. See also The Online Platform Economy: What is the growth trajectory?, JPMORGAN CHASE \& Co. (Feb. 18, 2016), https://www.jpmorganchase.com/ corporate/institute/insight-online-platform-econ-growth-trajectory.htm.

See Molly Cohen \& Arun Sundararajan, Self-Regulation and Innovation in the Peerto-Peer Sharing Economy, 82 U. Chi. L. Rev. Dialogue 116, 116 (2015).
} 
new form of labor for women's economic equality and security.

On the one hand, the new online, free-access "sharing" economy form of laboring shows great promise for enhancing women's economic equality through participation in the online workforce for two main reasons. The first is that, at least in some cases, laborers enjoy a greater degree of anonymity and potential inclusiveness when offering services online, which could offset bias, barriers, and discrimination still faced by women in the general workforce. This may be especially true if anonymity and gender-blindness are preserved in online platforms, which is often not the case; but it may potentially also be the case if anonymity is not preserved, given the gender discrepancies in pay, promotion, and opportunities the workplace has long exerted. ${ }^{26}$ Given that some "sharing" economy work is based online rather than in-person, and is horizontal rather than hierarchal, women may also find it easier to negotiate for equal pay. After all, the income generated by the same online task should not be affected by the laborer's gender.

The second reason for optimism is that in most cases, laborers in the "sharing" economy enjoy a substantial degree of flexibility in setting their work schedules. ${ }^{27}$ That flexibility is especially important

${ }^{26}$ For the persistent existence of the wage gap, see generally Fact Sheet: The Wage Gap Is Stagnant in the Last Decade, NAT'L Women's L. CTR. (Sept. 2013), http://www.nwlc.org/sites/default/files/pdfs/wage_gap_is_stagnant_2013_2.pdf.

The National Women's Law Center data is only on full-time earners. The wage gap is even more severe for the many women who are relegated to part-time, temporary, contingent work. See Labor Force Statistics from the Current Population Survey, UnITED STATES DEP'T OF LABOR, http://www.bls.gov/cps/aa2014/cpsaat37.htm (last visited Jan. 2, 2017) (revealing that women's median wages for full-time, year-round work were $82 \%$ of their male counterparts'); BUREAU LABOR STATISTICS, U.S. DEP'T OF LAB., Highlights OF WOMEN'S EARNINGS IN 2008, at 1-2 (2009), http://www.bls.gov/opub/reports/womens-

earnings/archive/womensearnings_2008.pdf (showing occupational segregation and generally lower earnings for women than men); On Pay Gap, Millennial Women Near Parity_For Now, Pew RESEARCH CTR. (Dec. 11, 2013), http://www.pewsocialtrends.org/2013/12/11/on-pay-gap-millennial-women-nearparity-for-now (showing young women are making progress and starting their working lives earning nearly the same as young men). See also Deborah L. Rhode, What WOMEN WANT: AN AGENDA FOR THE WOMEN's MOVEMENT 7, 25-38 (2014) (discussing a persistent gender gap in leadership); Christianne Corbett \& Catherine Hill, Graduating to a Pay Gap: The Earnings of Women and Men One Year after College Graduation, AM. Ass'N OF UnIV. Women (Oct. 2012), http://www.aauw.org/files/2013/02/graduating-to-apay-gap-the-earnings-of-women-and-men-one-year-after-college-graduation.pdf (reporting that women earn less than men already one year after graduation, across different occupations). See generally MARIA CHARLEs \& DAVID GRUSKY, OCCUPATIONAL Ghettos: The Worldwide SEgregation of Women AND Men (2004) (reporting that men and women still work in significantly segregated occupations).

27 Carboni, supra note 6; Drive with Uber: Earn money on your schedule, UBER, 
for working caregivers, who are still predominately women. ${ }^{28}$ Indeed, it seems like "sharing" economy companies are aiming to attract women using precisely these rationales: these companies market themselves as empowering women by providing them with the flexibility they need to balance work with family and other gendered responsibilities. ${ }^{29}$ Work and family both carry great significance in most people's lives, so providing shorter work hours and flexible schedules for both men and women may potentially prove beneficial in the search for work-family balance. ${ }^{30}$ On its face, then, the mushrooming of the "sharing" economy might be seen as a positive force for women's empowerment and equality. After all, the idea is that in the "sharing" economy a person is the designer of her labor. With no boss to tell her when to work, or which assignments to take on, she is the architect of her work life. Additionally, the flexibility of the "sharing" economy offers to both men and women the promise of gainful employment alongside family-care, potentially even changing the normalized gendered roles of caretaking and breadwinning. ${ }^{31}$

However, the view of cyberspace as an ideal realm where all can participate equally, free from historical, social, and physical restraints has already been critiqued as utopian. ${ }^{32}$ The picture does indeed look

https://get.uber.com/drive/ (last visited Dec. 17, 2016).

See Kathryn Abrams, Gender Discrimination and the Transformation of Workplace Norms, 42 VAND. L. REv. 1183, 1195, 1235 (1989); Arianne Renan Barzilay, Parenting Title VII: Rethinking the History of the Sex Discrimination Prohibition, 28 YALE J.L. \& FEMINISM 55, 100 (2016).

${ }^{29}$ For example, Uber has stated:

$[$ F] reedom is helping (literally) drive another wave of women's empowerment: the opportunity to fit work around life, rather than the other way around. Around 20 million Americans work fewer hours than they would like for "non-economic reasons," according to the Bureau of Labor Statistics. These include personal commitments, in particular child care, that can make full-time jobs so difficult.... It's one of the reasons Uber last year announced a commitment to get one million women drivers using our app by 2020. Because driving a car isn't just a way to get to work-it can be the work. For women around the world, Uber offers something unique: work on demand, whenever you want it. Drivers can make money on their own terms and set their own schedules.

Blaire Mattson, This International Women's Day, Women Take the Wheel, UbER NewsRoom (Mar. 7, 2016), https://newsroom.uber.com/driven-women.

30 See Arianne Renan Barzilay, Back to the Future: Introducing Constructive Feminism for the Twenty-First Century-A New Paradigm for the Family and Medical Leave Act, 6 HARV. L. \& POL'y REV. 407, 432-35 (2012).

31 See Joan C. Williams, Reshaping the Work-Family Debate, Why Men AND Class MATTER 2 (2010) (discussing how workplace norms pressure men into breadwinning roles and women out of them). For the gendered roles of caretaking and breadwinning, see Cahn, supra note 21, at 188, 191, 200-01, 214.

32 See Mary Anne Franks, Unwilling Avatars: Idealism and Discrimination in Cyberspace, 
far more complicated, in the context of platform-facilitated, ondemand labor. Companies like Uber treat drivers as contractors rather than employers, thereby avoiding worker protections such as overtime, minimum wage, family leave, and unemployment insurance. ${ }^{33}$ Of course, freelancing, temp work, and telecommuting have been around for a long time, but the "sharing" economy's rapid growth in recent years has given rise to a growing online service economy that applies the contract-worker model across various sectors. This trend has a dramatic influence on the workforce and the organization of employment, as the volume, ease, and scope of online precarious labor is increasing. ${ }^{34}$ According to some evaluations, by $2020,40 \%$ of American workers will be working as independent contractors, ${ }^{35}$ likely making platform-facilitated labor even more popular. These so-called contracting, freelancing, or "tasking" work models require far less investment in workers, offer fewer opportunities for workers to establish relationships with employers, and provide fewer benefits and a paucity of protections against discrimination than do long-term or full-time employment models. ${ }^{36}$ Additionally, the sheer number of online taskers competing for a given task may encourage the lowering of bidding rates. ${ }^{37}$ Along with information gaps about the actual work a given task entails, the pressure to lower one's price may generate exploitative work practices. ${ }^{38}$

20 COLUM. J. GENDER \& L. 224, 225 (2011).

33 Deepa Das Acevedo, Regulating Employment Relationships in The Sharing Economy, 20 EMP. RTS. \& EMP. POL'Y J. 1, 2 (2016) (noting that sharing economy work often entails no benefits). See Finkin, supra note 6, at 611,615 (explaining that when workers are not considered "employees" the purchaser of their labor need not bear benefits such as minimum wage, or family leave); see also Carboni, supra note 6; Henry Ross, Ridesharing's House of Cards: O'Connor v. Uber Technologies, Inc. and The Viability of Uber's Labor Model in Washington, 90 WASH. L. REV. 1431, 1431 (2015).

34 See Lobel, supra note 10, at 1; The Online Platform Economy: What is the growth trajectory?, JPMORGAN CHASE \& CO. (Feb. 2016), https:/ /www.jpmorganchase.com/ corporate/institute/insight-online-platform-econ-growth-trajectory.htm.

Joanna Penn \& John Wihbey, Uber, Airbnb and Consequences of the Sharing Economy: Research Roundup, JOURNALIST'S RESOURCE, http:/ /journalistsresource.org/studies/ economics/business/airbnb-lyft-uber-bike-share-sharing-economy-researchroundup\#sthash.XMg2yvqU.dpuf (last updated June 3, 2016). See also CunninghamParmeter, supra note 19, at 4 (citing INTUIT, INTUIT 2020 REPORT: TWENTY TRENDS THAT Will SHAPE THE NEXT DECADE 20 (2010)).

${ }^{36}$ See Vicki Schultz, Feminism and Workplace Flexibility, 42 CONN. L. REv. 1203 (2010); Michelle A. Travis, Equality in the Virtual Workplace, 24 BERKELEy J. EMP. \& LAB. L. 283 (2003).

37 See Finkin, supra note 6, at 617 (explaining how global competition may erode wages).

Brad Stone, My Life as a Taskrabbit: A Short Career in the Distributed Workforce, BloOMBERG (Sept. 13, 2012), http://www.bloomberg.com/news/articles/2012-09- 
One can argue that these work practices are actually preventing economic sustainability and equality for women, and that the "sharing" economy, far from helping laborers overcome the work-family conflict, may be worsening it by reducing the human subject to a mere commodity. Because detached and fragmented labor places the ideal of stable employment and self-sufficiency beyond the reach of many laborers, thereby requiring them to work for more hours to make ends meet, it may create numerous risks for workers and families. ${ }^{39}$ This form of labor may carry additional specific, gendered risks for caregivers. For example, arranging, scheduling, and providing childcare when one is an on-call worker makes juggling work and family even more difficult to sustain. ${ }^{40}$ Furthermore, some have claimed that the "sharing" economy heightens the salience of sex (because of the intimacy associated with some transactions and the accessibility to photographs and names online), which primes sexstereotypes, often considered harmful for gender equality. ${ }^{41}$

\section{EMPIRICAL FINDINGS}

Given the considerable theoretical benefits and challenges illustrated above, it is especially important to begin to empirically examine how women are actually faring in the online "sharing" economy. Women comprise a substantial share of "sharing" economy laborers. ${ }^{42}$ Women still do the lion's share of familial caregiving, while most lucrative jobs are constructed for workers free from such responsibilities. ${ }^{43}$ The attraction of flexible schedules, combined with women's second-class status in the workplace generally, ${ }^{44}$ may make women especially susceptible to the lure of fragmented tasking services. ${ }^{45}$ But to what degree are these new forms of work reorganizing

13/my-life-as-a-taskrabbit. For a more optimistic assessment of working in the sharing economy, see Lobel, supra note 10.

$39 \quad$ See Carboni, supra note 6.

40 See Miriam A. Cherry, A Taxonomy of Virtual Work, 45 GA. L. Rev. 951 (2011). See Angela P. Harris, Theorizing Class, Gender, and the Law: Three Approaches, 72 L. \& CONTEMP. PROBS. 37, 44-51 (2009) (stating that the gender divide is fundamental to economic production).

${ }^{41}$ Schoenbaum, supra note 17.

42 Katz \& Krueger, supra note 24, at 11-12 (observing a "notable rise in the share of workers in alternative work arrangements that are women"). See also Steinmetz, supra note 24.

43 See Williams, supra note 21, at 14-19.

44 Abrams, supra note 28, at 1191, 1196 (noting that women have been disadvantaged as workers by the fact that central features of the workplace have been constructed by and for men). See supra note 26 .

45 See Laura T. Kessler, The Attachment Gap: Employment Discrimination Law, Women's 
around the same gendered lines? Are the new platforms enhancing women's opportunities in important and substantial ways, or are they merely replicating "old" economy gender inequality?

Social science data has long pointed to the persistent existence of a wage and leadership gap and of occupational segregation in the workplace. ${ }^{46}$ The Internet has been critiqued as a place in which sexual harassment has dramatic discriminatory effect on women, and in which women have had to silence their potentially rewarding online presences due to cyber harassment. ${ }^{47}$ Some attention has recently been paid to the "sharing" economy's possible effects on underprivileged groups like racial minorities, ${ }^{48}$ and new research has shown that blacks are discriminated against on Airbnb. ${ }^{49}$ Some have found that customer satisfaction ratings (important tools for users on various platforms) overwhelmingly favored men over women. ${ }^{50}$ Women have been found to receive less money than men when selling the same merchandise on eBay. ${ }^{51}$ But how is gender playing out in the unregulated online "sharing" economy labor context? Do women still earn less than men, even online? Are the age-old maladies confronted by women in the "old" economy morphed through technology in the new one?

There is an acute shortage of data analyzing online platform work from a gender perspective. We investigate a global online platform that connects work-seekers of various occupations with online tasks to be performed. We use data from the studied platform as a case study through which to examine gendered dimensions of work in the "gig" economy. On the studied platform, people can register either as workseekers or as potential work-providers. Work-seekers create profiles in which they provide information about the services they perform, their

Cultural Caregiving and the Limits of Economic and Liberal Legal Theory, 34 U. MICH. J.L. REFORM 371 (2001) (arguing that a lack of parental leave policies creates an "attachment gap" for women in the workforce).

${ }^{46}$ See supra note 26 and accompanying text.

47 Franks, supra note 32.

48 Nancy Leong, The Sharing Economy Has a Race Problem, SAlon (Nov. 2, 2014), http://www.salon.com/2014/11/02/the_sharing_economy_has_a_race_problem.

49 Benjamin G. Edelman \& Michael Luca, Digital Discrimination: The Case of Airbnb.com (Harvard Bus. Sch., Working Paper No. 14-054, 2014), http:/ / papers.ssrn.com/sol3/papers.cfm?abstract_id=2377353; Benjamin Edelman, Michal Luca \& Dan Svirsky, Racial Discrimination in the Sharing Economy: Evidence From a Field Experiment (Harvard Bus. Sch., Working Paper No. 16-069, 2016), http:/ / papers.ssrn.com/sol3/papers.cfm?abstract_id=2701902.

Larry Kim, Gender Bias in Online Marketing: Data Shows Women Are Undervalued by $21 \%$, WORDSTREAM (Apr. 3, 2015), http://www.wordstream.com/blog/ws/2014/05/ $13 /$ gender-bias.

${ }_{51}$ Tamar Kricheli-Katz \& Tali Regev, How Many Cents on the Dollar? Women and Men in Product Markets, 2 SCI. Advances 1 (2016). 
skills, and their requested "hourly rate." ${ }^{, 52}$ There is no box to check on the profile page for the gender of work-seekers, but names are required and photographs are commonly used as profile pictures. ${ }^{53}$ Potential work-providers post jobs to which work-seekers apply. After the potential work-provider reviews the profiles of those who have applied, they may contact those who seem the most fitting to complete the online task. ${ }^{54}$ After an interview, which usually takes place outside of the Platform (such as via email or phone), the work-provider sends an offer to the work-seeker and when the work-seeker accepts the terms, a contract is signed..$^{55}$ After the task is completed, the Platform transfers pay via an escrow account. The work-provider then rates the performance of the work-seeker, which appears on her profile as a "feedback score." ${ }^{\text {"f6 }}$ The Platform collects its fee as a percentage of every transaction. ${ }^{57}$

\section{A. Method}

Traditionally, studies on the gender pay gap primarily rely on data obtained from surveys, coupled with demographic data. ${ }^{58}$ By contrast, in this study we undertake a computational approach to measuring gendered dimensions of working on the Platform by extracting profile data from its Application Programming Interface (API). Rather than relying on surveys or questionnaires that are based on answers or data reported by users, extracting the data from the Platform's API enables us to capture a snapshot of the actual user profiles that are in use on the Platform. Since we aim to examine the gendered dimensions of working via an online platform, and because the "gig" economy is operating through platforms, the application of computational, unobtrusive methods is tailored to capture the unique digital aspects of the "gig" economy, by providing a snapshot of the actual digital interactions that the Platform hosts, as they are shaped by its technological affordances ${ }^{59}$ and as they are made available through

52 This information appears on the Platform's website (link on file with authors). Id.

Id.

$I d$.

$I d$.

$I d$.

See supra note 26.

59 The term "technological affordances" relates to the ways with which technology shapes sociability. It examines the ways humans (users), perceive objects as possibilities for potential actions and act upon them. The term is widely used by scholars of social media platforms. See, e.g., Ester Weltevrede \& Erik Borra, Platform Affordances and Data Practices: The Value of Dispute on Wikipedia, 3 BIG DATA \& SOC'Y 1 (2016). 
the Platform's API. ${ }^{60}$

As a first step, we collected data. After gaining permission from the Platform to access their API, we built a python script to automatically extract a sample of users' profile data according to the following parameters: 1) profiles from the U.S.; 2) profiles of private people (as opposed to agencies that provide services through its workers); and 3) profiles that were active on the Platform between June 2015 and March 2016. In total, we retrieved 24,000 user profiles within these dimensions.

Subsequently, we set to obtain a pool of gender identifiable profiles. While the Platform does not provide a specified field for gender in the user profile, the gender of a user is known to people or companies who provide work opportunities either through the user's name, or through their profile picture. Therefore, in order to automatically determine the gender of the extracted profiles, we used two web services:

a. Genderize.io, a web service aimed at identifying gender based on English names. ${ }^{61}$

b. Angus.ai, a web service aimed at identifying gender based on photos. $^{62}$

To validate the automated gender identification of the extracted profiles, we only selected profiles in which both services indicated an $80 \%$ or more certainty about the gender, and additionally, we compared the findings of each service with the other, and only took profiles that both services identified as the same gender. After comparing both services, we remained with profiles whose average gender accuracy was $98 \%$ for name identification and $96 \%$ for photos. After this, 4,669 profiles remained.

From the extracted profile data, we further selected fields for analysis according to fields articulated by the Platform's API: 1) Occupational Category ("Accounting \& Consulting," "Admin Support," "Customer Service," "Data Science \& Analytics," "Design \& Creative," "Engineering \& Architecture," "IT \& Networking," "Legal," "Sales \& Marketing," "Translation," "Web, Mobile \& Software Development," "Writing"); 2) "Hourly Rate" - the hourly pay rate determined by the work-seeker; 3) "Feedback Score" - a score on a scale of one to five given to the user by those who utilized the user's

${ }^{60}$ See Christine Hine, Internet Research and Unobtrusive Methods, 61 SOC. RES. UPDATE 1 (2011) (presenting the benefits of such an approach).

61 See Determine the Gender of a First Name, GENDERIZE.IO, https:/ /genderize.io/ (last visited Dec. 12, 2016).

62 See ANGUS.AI, https://www.angus.ai/ (last visited Sept. 21, 2016). 
labor after completing a task through the Platform: this field shows the average feedback score a user received from previous assignments; and 4) "Total Hours" - the accumulative number of hours a user worked through the Platform. Note that in our dataset the total number of hours does not include tasks billed with a fixed price, but only those with an hourly rate.

To further enrich the analysis, we computed two additional fields based on the data extracted from the API. The first is years of experience. From the profiles' self-description field, we automatically extracted the description of previous work, and calculated years of experience as a subtraction of the first year from the last year worked in each previous job. We added the number of years worked in each previous work to calculate an estimate of the user's work experience in years. Parallel jobs conducted in the same year were excluded from the calculation of this field, so as not to skew the data.

The second computed field is the level of education attainment. The education field returned by the Platform's API contains all degrees mentioned by a given profile. To determine a profile's level of education, we manually selected the highest degree mentioned, and kept it in a separate field we called "degree." Subsequently, we clustered the different degrees into the following categories of level of education attainment: high school, associate degrees, bachelor degrees (undergraduate), master's degrees (graduate), and doctorate degrees (including J.D.). Since the extraction of the highest degree was performed manually, the field of level of education attainment was computed only on the occupational category "Legal."

Finally, we used descriptive statistics and regression models to analyze the data. Specifically, we computed the differences in the average hourly rate of women and men across all occupational categories, and used a standard t-test to compare mean differences by gender within occupational category. After confirming that there are significant interactions between occupational categories and the hourly rate, we subsequently conducted a two-way analysis of variance ("ANOVA") with the log of the hourly rate in order to assess the effect of gender on the hourly pay in each occupational category. We then repeated the model, each time testing for possible interactions with the following variables: "feedback score," "years of experience," and "total hours" worked on the Platform. Finally, we used a linear regression model on the log of the hourly rate to compute the ratio in the hourly rate of women and men in each occupational category, as well as for all categories taken together. 


\section{B. Findings}

Our findings show a dramatic gender gap in platform-facilitated online work, on the Platform. They show that although the overall number of male and female profiles in the dataset is equally distributed $(\mathrm{N}=2321$ women, $2348 \mathrm{men})$, and so is the average feedback score of male and female profiles (3.21 for women, 3.17 for men), women have worked a larger total number of hours $(\mathrm{N}=$ $773,666)$ than men $(\mathrm{N}=611,912)$. However, on average, women's hourly rate is $37 \%$ lower than men's: the overall average hourly rate for women is $\$ 28.20$ per hour, compared to an average hourly rate of $\$ 45.07$ for men. It should be noted that the proportion between female and male profiles varies across the different occupational categories (see Figure 1), and so does the gap in the hourly rate of men and women in each category (see Figure 2). Half of the occupational categories $(\mathrm{N}=6)$ are populated by more women than men, namely, Customer Service ( $77 \%$ women), Admin \& Support ( $73 \%$ women), Legal ( $70 \%$ women), Translation $(65 \%$ women), Writing $(65 \%$ women), and Sales \& Marketing (62\% women). Three categories have more male profiles: Engineering \& Architecture (83\% men), IT \& Networking ( $82 \%$ men), and Data Science \& Analytics ( $73 \%$ men). In the remaining categories $(\mathrm{N}=3)$ male and female profiles are more or less equally distributed: Accounting \& Consulting ( $54 \%$ women), Web, Mobile \& Software Development (49\% women), and Design \& Creative ( $44.1 \%$ women).

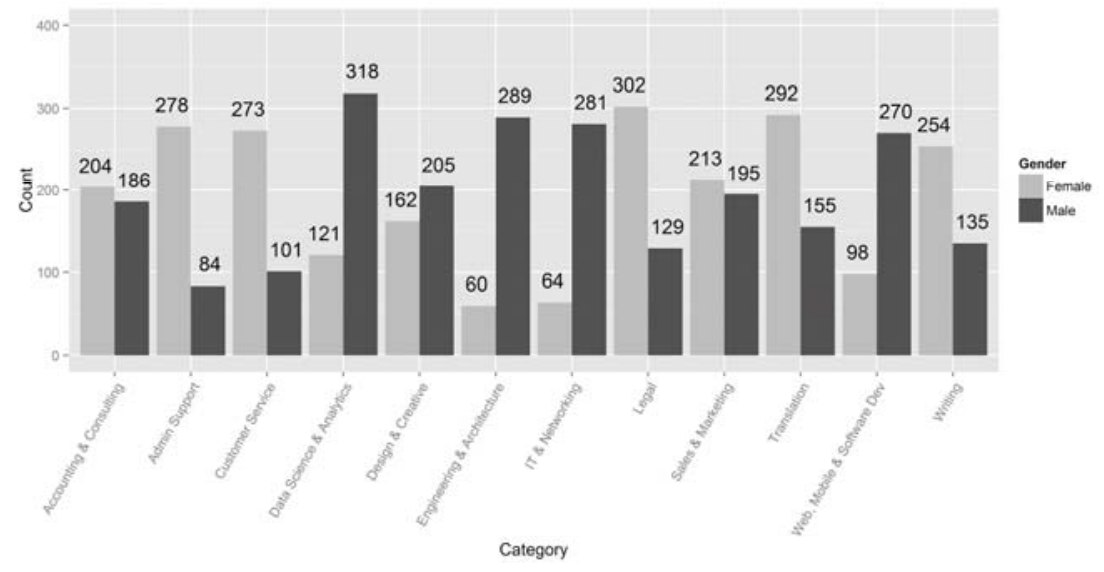

Figure 1. The number of male and female profiles in each occupational category. 


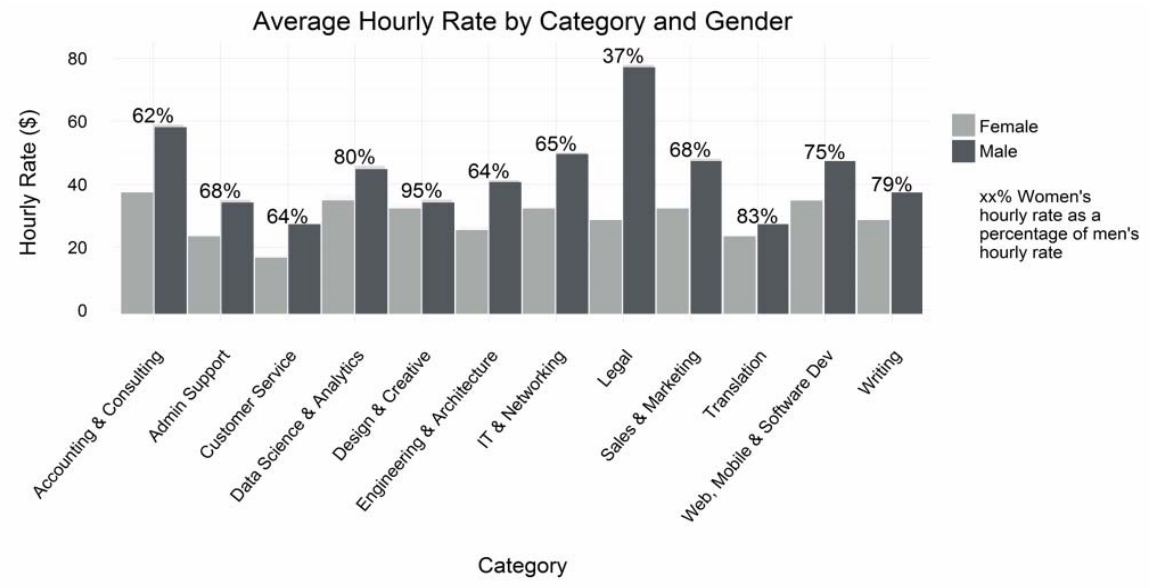

Figure 2. Average hourly rate by occupational category and gender.

Table 1 shows a breakdown of the average hourly rate per occupational category. Since the distribution of the average hourly rate was not normal, we conducted a t-test to compare differences on the log of the average hourly rate of men and women. We report that the hourly rate gap exists in all categories, albeit with significant differences between categories. For example, "Legal" stands out as the occupational category where the average hourly rate of women makes only $37 \%$ of men's $100 \%$. At the other extreme, women's profiles in the "Design \& Creative" category have an average hourly rate that is almost equal to that of men $(95 \%)$. A significant hourly rate gap is reported for categories with a majority of female profiles. In the categories "Accounting \& Consulting" and "Customer Service," for example, the average hourly rate of women is only $62 \%$ and $64 \%$, respectively, of the average hourly rate of men. Although in the categories "Translation" and "Writing," where there is also a majority of female profiles, the reported average hourly rate gap is narrower ( $79 \%$ and $83 \%$, respectively), the differences between the average log of the hourly rate of men and women in these categories have not been found statistically significant (see Table 1). In categories with a majority of men's profiles, the hourly rate gap varies from $65 \%$ in "IT \& Networking" to $80 \%$ in "Data Science \& Analytics." 
Table 1. T-test on Log of Hourly rate

\begin{tabular}{|c|c|c|c|c|c|c|}
\hline & & \multicolumn{4}{|c|}{$\underline{\text { Hourly rate }}$} & $\begin{array}{l}\text { T-test } \\
\text { on the } \log \\
\text { of Hourly } \\
\text { rate }\end{array}$ \\
\hline Category & $\underline{\text { Gender }}$ & $\underline{\mathrm{N}}$ & $\underline{\text { Mean }}$ & $\underline{\text { Std }}$ & $\begin{array}{l}\text { Female } \\
\text { compared } \\
\text { to Male }\end{array}$ & $\underline{\text { Significance }}$ \\
\hline $\begin{array}{l}\text { Accounting \& } \quad \& \\
\text { Consulting } \\
\end{array}$ & $\begin{array}{l}\underline{\text { female }} \\
\underline{\underline{\text { male }}}\end{array}$ & $\underline{186}$ & $\underline{58.96}$ & $\begin{array}{l}\underline{46.05} \\
\underline{55.34} \\
\end{array}$ & $\underline{-38 \%}$ & $\underline{* * *}$ \\
\hline Admin Support & $\begin{array}{l}\underline{\text { female }} \\
\underline{\text { male }}\end{array}$ & $\begin{array}{l}\underline{278} \\
\underline{84}\end{array}$ & $\begin{array}{l}\underline{23.86} \\
\underline{35.03}\end{array}$ & $\begin{array}{l}\underline{14.99} \\
\underline{25.79} \\
\end{array}$ & $-32 \%$ & **** \\
\hline Customer Service & $\begin{array}{l}\underline{\text { female }} \\
\underline{\text { male }}\end{array}$ & $\begin{array}{l}\underline{273} \\
\underline{101}\end{array}$ & $\begin{array}{l}\underline{17.26} \\
\underline{26.97} \\
\end{array}$ & $\begin{array}{l}\underline{10.03} \\
\underline{27.55} \\
\end{array}$ & $-36 \%$ & **** \\
\hline $\begin{array}{l}\text { Data Science \& } \\
\underline{\text { Analytics }} \\
\end{array}$ & $\begin{array}{l}\underline{\text { female }} \\
\underline{\text { male }}\end{array}$ & $\underline{318}$ & $\underline{45.83}$ & $\begin{array}{l}\underline{40.33} \\
\underline{34.66} \\
\end{array}$ & $\underline{-20 \%}$ & **** \\
\hline Design \& Creative & $\begin{array}{l}\underline{\text { female }} \\
\underline{\text { male }}\end{array}$ & $\begin{array}{l}\underline{162} \\
\underline{205}\end{array}$ & $\begin{array}{l}\underline{33.50} \\
\underline{35.13}\end{array}$ & $\begin{array}{l}\underline{24.87} \\
\underline{23.53} \\
\end{array}$ & $-5 \%$ & \\
\hline $\begin{array}{l}\text { Engineering \& } \\
\text { Architecture } \\
\text { - }\end{array}$ & $\begin{array}{l}\underline{\text { female }} \\
\underline{\text { male }}\end{array}$ & $\underline{289}$ & $\underline{41.31}$ & $\begin{array}{l}\underline{15.69} \\
\underline{26.08}\end{array}$ & $-36 \%$ & $* * *$ \\
\hline IT \& Networking & $\begin{array}{l}\text { female } \\
\underline{\text { male }}\end{array}$ & $\begin{array}{l}\underline{64} \\
\underline{281}\end{array}$ & $\begin{array}{l}\underline{32.72} \\
\underline{50.01} \\
\end{array}$ & $\begin{array}{l}\underline{24.60} \\
\underline{40.61} \\
\end{array}$ & $-35 \%$ & **** \\
\hline Legal & female & $\underline{302}$ & $\underline{28.88}$ & $\underline{31.86}$ & $-63 \%$ & *** \\
\hline
\end{tabular}




\begin{tabular}{|c|c|c|c|c|c|c|}
\hline & $\underline{\text { male }}$ & $\underline{129}$ & $\underline{77.93}$ & $\underline{71.04}$ & & \\
\hline \multirow[t]{2}{*}{ Sales \& Marketing } & female & 213 & $\underline{32.50}$ & 22.44 & \multirow[t]{2}{*}{$-32 \%$} & \multirow[t]{2}{*}{ **** } \\
\hline & $\underline{\text { male }}$ & $\underline{195}$ & $\underline{48.10}$ & $\underline{36.69}$ & & \\
\hline \multirow[t]{2}{*}{ Translation } & female & $\underline{292}$ & 22.57 & $\underline{13.78}$ & \multirow[t]{2}{*}{$\underline{-17 \%}$} & \\
\hline & male & 155 & 27.03 & 22.06 & & \\
\hline \multirow{3}{*}{$\begin{array}{l}\text { Web, Mobile \& } \\
\text { Software Dev }\end{array}$} & & & & & \multirow{3}{*}{$-25 \%$} & \multirow{3}{*}{$\underline{* *}$} \\
\hline & female & $\underline{98}$ & $\underline{35.41}$ & $\underline{19.45}$ & & \\
\hline & male & 270 & 47.38 & 37.67 & & \\
\hline \multirow[t]{2}{*}{ Writing } & female & $\underline{254}$ & $\underline{29.13}$ & $\underline{21.15}$ & \multirow[t]{2}{*}{$-21 \%$} & \\
\hline & male & $\underline{135}$ & $\underline{37.10}$ & $\underline{35.27}$ & & \\
\hline \multirow[t]{2}{*}{$\underline{\text { ALL }}$} & female & $\underline{2321}$ & $\underline{28.20}$ & $\underline{26.01}$ & \multirow[t]{2}{*}{$-37 \%$} & \multirow[t]{2}{*}{ **** } \\
\hline & male & 2348 & $\underline{45.07}$ & $\underline{39.65}$ & & \\
\hline
\end{tabular}

$* \mathrm{P}<.05 * * \mathrm{P}<.01 * * * \mathrm{P}<.001$

In order to verify that the differences in the hourly rate of women and men are not a result of other factors, several alternative explanations were tested. Specifically, we attempted to rule out that the occupational category itself, the years of experience worked outside of the Platform, the feedback score or the total hours worked on the Platform are the variables that account for most of the differences found in the hourly rate of women and men. A two-way analysis of variance ("ANOVA") model shows that the interaction between gender and the occupational category has a significant effect $(\mathrm{F}=40.19, \mathrm{p}<0.001, \mathrm{R}$-square $=0.165)$. See Table 2.

Table 2: Two-way ANOVA on the log of the hourly rate

\begin{tabular}{|rrrrrr} 
Source & DF & Sum of & Mean & F & Pr $>$ F \\
& & Squares & Square & Value & \\
& & & & & \\
Model & 23 & 400.133947 & 17.397128 & $40.19<.0001$
\end{tabular}




\begin{tabular}{|lrrrrr}
\hline Source & DF & Sum of & Mean & F Pr $>$ F \\
& & Squares & Square & Value & \\
& & & & \\
Error & 4645 & 2010.480699 & 0.432827 & \\
& & & & \\
Corrected & 4668 & 2410.614646 & & \\
Total & & & &
\end{tabular}

R-Square Coeff Var Root MSE log hourly rate mean

$\begin{array}{llll}0.165988 & 19.79749 & 0.657896 & 3.323126\end{array}$

\begin{tabular}{|lrrrrrr}
\hline Source & DF & Type III SS & Mean & F & Pr $>$ F \\
& & & & Square & Value & \\
& & & & & \\
Category & 11 & 165.7583917 & 15.0689447 & 34.82 & $<.0001$ \\
Gender & 1 & 94.0194458 & 94.0194458 & $217.22<$ & $<.0001$ \\
& & & & & & \\
Category*Gender & 11 & 41.2556977 & 3.7505180 & 8.67 & $<.0001$ \\
\end{tabular}

Furthermore, gender remained a significant predictor of the hourly rate when each of the other independent variants (years of experience, feedback score, hours of work) was added to the model. For example, there is a significant interaction between years of experience and the log of the hourly rate. However when the variant years of experience was added to the model together with gender and occupational category, the interaction between gender and the log of the hourly rate remained significant $(\mathrm{F}=39.20, \mathrm{p}<0.001, \mathrm{R}$-square $=$ 
0.19). A two-way multivariate analysis of variance ("MANOVA") model, comparing gender, occupational category, feedback score, years of experience and the total hours worked on the Platform resulted in a significant multivariate effect $(\mathrm{F}=19.64, \mathrm{p}<0.001$, R-square $=0.18) .^{63}$ See Table 3. This confirms that the alternative explanations to the differences found in the hourly rate of women and men do not rule out the significant effect of gender.

Table 3. Two-way MANOVA on the log of the hourly rate.

\begin{tabular}{|lrrrrr|}
\hline Source & DF & Sum of & Mean & F Pr $>$ F \\
& & Squares & Square & Value & \\
& & & & & \\
Model & 26 & 187.924453 & 7.227864 & $19.64<.0001$ \\
Error & 2249 & 827.657393 & 0.368011 & \\
Corrected & 2275 & 1015.581846 & & \\
Total & & & & & \\
\end{tabular}

R-Square Coeff Var Root MSE log hourly rate mean

$\begin{array}{llll}0.185041 & 17.97336 & 0.606639 & 3.375214\end{array}$

63 Note that the variant "Total hours" was computed on values that are larger than zero, therefore only relating to people who have already completed hourly work on the Platform $(\mathrm{N}=2275)$. 


\begin{tabular}{|c|c|c|c|c|c|}
\hline Source & DF & Type III SS & Mean & $\mathrm{F}$ & $\operatorname{Pr}>\mathrm{F}$ \\
\hline & & & Square & Value & \\
\hline Category & 11 & 39.98418673 & 3.63492607 & 9.88 & $<.0001$ \\
\hline Gender & 1 & 61.79873027 & 61.79873027 & 167.93 & $<.0001$ \\
\hline Category*Gender & 11 & 13.83327945 & 1.25757086 & 3.42 & 0.0001 \\
\hline Feedback Score & 1 & 5.00322945 & 5.00322945 & 13.60 & 0.0002 \\
\hline Experience & 1 & 12.77920923 & 12.77920923 & 34.73 & $<.0001$ \\
\hline Total Hours & 1 & 1.32609520 & 1.32609520 & 3.60 & 0.0578 \\
\hline
\end{tabular}

Since we found significant interaction between the occupational category and the hourly rate, and after confirming that the profiles in each category are unique, we further conducted separate regression analyses on the effect of gender on the hourly rate for each of the twelve occupational categories, as well as for all categories taken together. As can be seen in Table 4, with the exception of the categories "Design \& Creative," "Translation" and "Writing," we found a significant effect of gender on the hourly rate. We subsequently converted the difference in the log values of the hourly rate of women and men into a ratio of women's hourly rate out of men's. We can therefore confirm that in nine out of the twelve occupational categories there are statistically significant gaps in the hourly rate of women compared to men. For example, in the "Customer Service" category, women's hourly rate is $73 \%$ of what their male peers requested. In the "Legal" category, women's hourly rate is as low as $44 \%$ of the hourly rate asked by men. Finally, we report that after controlling for the separate effect of gender on the hourly rate in each of the occupational categories, when all occupational categories are taken together, women's hourly rates are only $66 \%$ of what men request. This figure corresponds with the $37 \%$ gap reported for the differences in the average hourly pay for men and women at the outset of the findings section. 
Table 4. Regression analysis of gender on the log of the hourly rate

\begin{tabular}{|l|l|l|l|l|}
\hline & & $\begin{array}{l}\text { Regression } \\
\text { coefficient } \\
\text { of female vs. }\end{array}$ & & Female/ \\
& & male & male \\
Category & (on log of & & ratio (on \\
\hline Accounting \& & 390 & -0.4752 & $* * *$ & Hourly \\
\hline Consulting & & & Significance & rate) \\
\hline Admin Support & 362 & -0.3122 & $* * *$ & 0.62 \\
\hline Customer Service & 374 & -0.2893 & $* * *$ & 0.73 \\
\hline Data Science \& & 439 & -0.2826 & $* * *$ & 0.75 \\
\hline Analytics & & & & 0.75 \\
\hline Design \& & 367 & -0.0516 & NS & 0.66 \\
\hline Ereative & & & & \\
\hline Legal & & & & \\
\hline & & & & \\
\hline
\end{tabular}


[Vol. 47:393

\begin{tabular}{|c|c|c|c|c|}
\hline $\begin{array}{l}\text { Sales \& } \\
\text { Marketing }\end{array}$ & 408 & -0.3436 & $* * *$ & 0.71 \\
\hline Translation & 447 & -0.1086 & NS & 0.90 \\
\hline $\begin{array}{l}\text { Web, Mobile \& } \\
\text { Software } \\
\text { Development }\end{array}$ & 368 & -0.2112 & $* *$ & 0.81 \\
\hline Writing & 389 & -0.1378 & $\mathrm{NS}$ & 0.87 \\
\hline ALL & $\begin{array}{l}466 \\
9\end{array}$ & -0.4109 & $* * *$ & 0.66 \\
\hline
\end{tabular}

We have seen that the category "Legal" somewhat deviates from the other categories under examination, since it displays the largest gap between the average hourly rate of men and women, but our t-test on the log of the average hourly rate of men and women was not statistically significant. In order to further understand the outstanding hourly rate gap found in the "Legal" category, we examined its internal distribution. As Figure 3 shows, the hourly rate distribution of women in this category is highly skewed, with the vast majority of profiles offering the lower end of the hourly rate scale. 


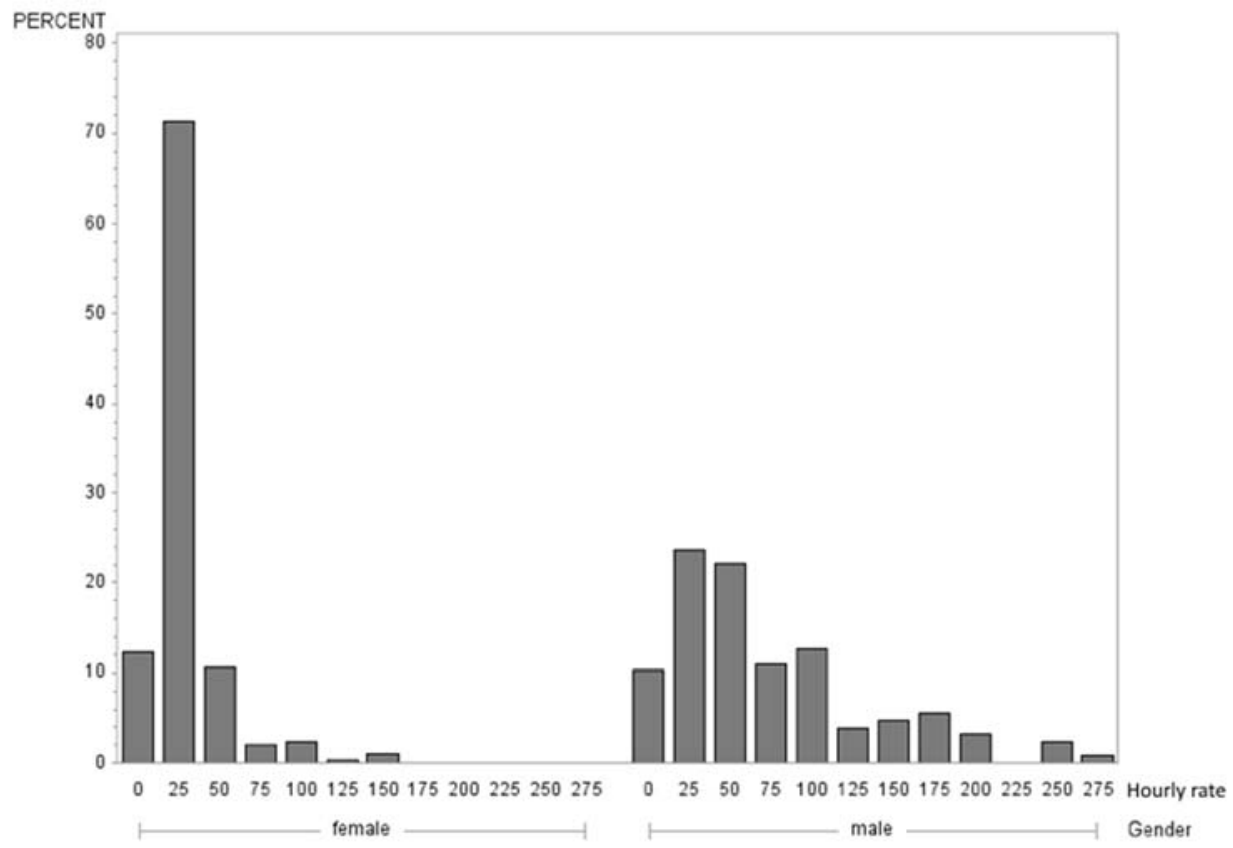

Figure 3. Distribution of hourly rate of male and female profiles in the "Legal Category."

One possible explanation for this huge gap is the fact that, in the studied platform, the "Legal" category hosts a variety of tasks and skills, from paralegals to attorney-at-law. Therefore, we further examined the ties between gender, years of experience, and the level of education in this category. As Figure 4 shows, the hourly rate gap is apparent in all ranges of work experience. When the hourly rate gap between women and men is compared against the level of education in the "Legal" category, the findings are even more striking: while at the associate degree level the average hourly rate of women is $106 \%$ that of men, at the undergraduate level there is already a gap of $65 \%$ in favor of men, and at the graduate level (which includes LL.M., M.B.A., etc.) the average hourly rate of women makes only $34 \%$ of the average hourly rate of men. At the doctorate level (J.D.) women J.D.'s hourly rates are $55 \%$ to men's $100 \%$ (see Figure 5). A regression model on the effect of gender, years of experience, the level of education on the log of the hourly rate in the legal category confirms that the effect of gender remains significant even given other factors that explain the variance in the hourly rate $(\mathrm{F}=31.87, \mathrm{p}<0.001$, Rsquare $=0.28)$. See Table 5 . 
[Vol. 47:393

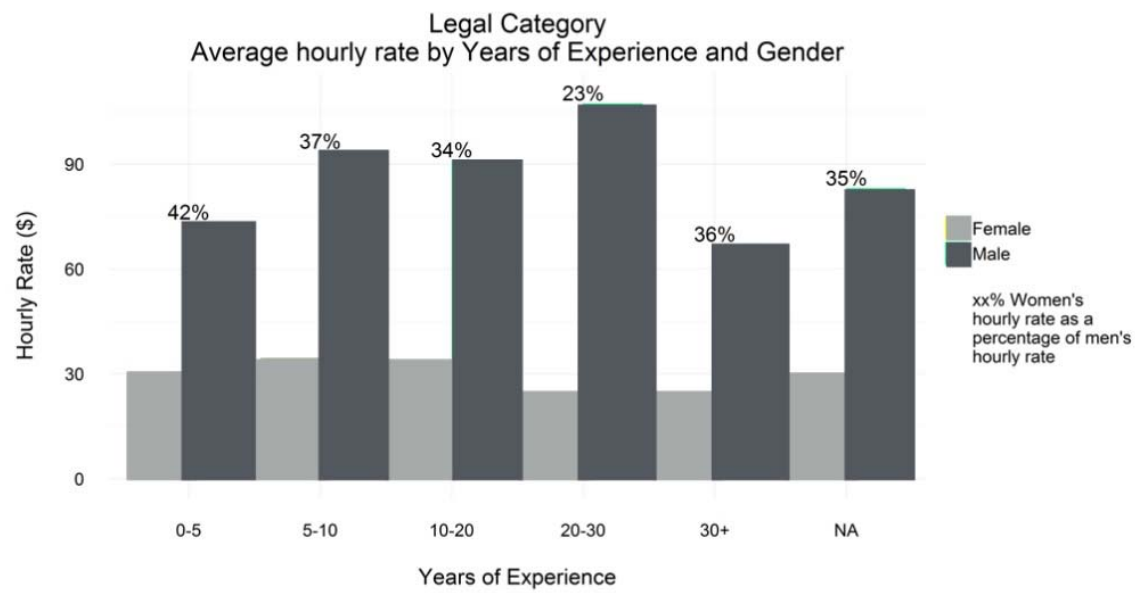

Figure 4. Legal category: Average hourly rate by years of experience and gender.

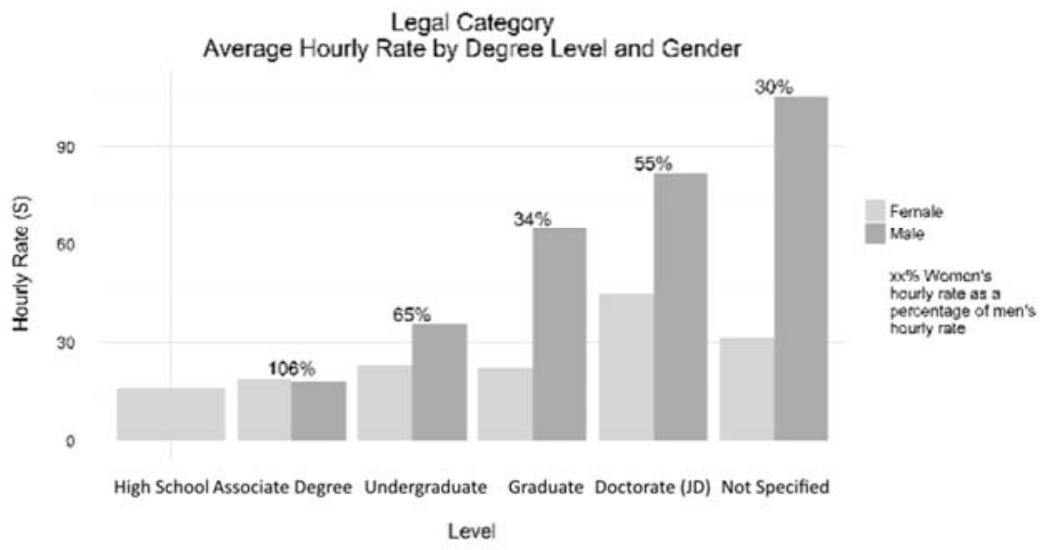

Figure 5. Legal category: Average hourly rate by level of education and gender. 
Table 5. "Legal" category: Regression model of the effect of gender, years of experience and level of education on the log of the hourly rate

Dependent Variable: $\log$ hourly rate

\begin{tabular}{|c|c|}
\hline Number of Observations Read & 431 \\
\hline Number of Observations Used & 239 \\
\hline ons with Missing Values & \\
\hline
\end{tabular}

\begin{tabular}{|c|c|c|c|c|c|}
\hline \multicolumn{6}{|c|}{ Analysis of Variance } \\
\hline \multirow[t]{2}{*}{ Source } & DF & Sum of & Mean & F Value & $\operatorname{Pr}>F$ \\
\hline & & Squares & Square & & \\
\hline Model & 3 & 43.34248 & 14.44749 & 31.87 & $<.0001$ \\
\hline Error & 235 & 106.53534 & 0.45334 & & \\
\hline Corrected Total & 238 & 149.87782 & & & \\
\hline
\end{tabular}

$\begin{array}{llll}\text { Root MSE } & 0.67331 & \text { R-Square } & 0.2892 \\ \text { Dependent Mean } & 3.33536 & \text { Adj R-Sq } & 0.2801 \\ \text { Coeff Var } & 20.18691 & \end{array}$




\begin{tabular}{|c|c|c|c|c|c|}
\hline \multicolumn{6}{|c|}{ Parameter Estimates } \\
\hline Variable & $\mathrm{DF}$ & Parameter & Standard & t Value & $\operatorname{Pr}>|t|$ \\
\hline & & Estimate & Error & & \\
\hline Intercept & 1 & 2.55237 & 0.20678 & 12.34 & $<.0001$ \\
\hline Gender (Female) & 1 & -0.45163 & 0.10090 & -4.48 & $<.0001$ \\
\hline Degree & 1 & 0.26824 & 0.04262 & 6.29 & $<.0001$ \\
\hline Experience & 1 & 0.01159 & 0.00559 & 2.07 & 0.0393 \\
\hline
\end{tabular}

\section{Discussion of Findings}

Our findings show that, on average, women's hourly rates are significantly lower than men's when considering the same tasks, despite similar levels of educational attainment, feedback score, and length of experience.

Two questions derive from this data. The first concerns women's undervaluation of themselves. This could be caused either by women's increased need for money (which may explain why they work more on the Platform), or because the online hourly rates are operating in the shadow of the offline market in which women often earn less than men. Should women simply post higher hourly rates? Literature on women and negotiations has identified a significant difference between men and women in their propensity to negotiate for wages and an a-priori lowering of salary expectations among women to avoid negotiation. ${ }^{64}$ Recently women have been publically urged to "lean-in" ${ }^{65}$ by demanding higher pay, for example. However, new research suggests that posting higher hourly rates may not always be beneficial for women. This research shows that when women are not

${ }^{64}$ See generally Linda Babcock \& SARA LASchever, Why Women Don't Ask: The High Cost of Avoiding Negotiation-and Positive Strategies for Change (2007).

65 Sheryl SANDBERG, LeAN In: WOMEN, Work, AND THE Will to LEAD (2013). 
sure what is expected in negotiations, or when those expectations are murky, asking for more money does not always work as well for women as it does for men, and may actually hurt women financially. ${ }^{66}$

A second question is whether there are actual differences in pay. The answer to this question relates to our dependence on the data provided by the Platform's API. Since the actual payment received by users per hour is not available for extraction from the Platform's API, we are unable to systematically analyze actual payment received by users per hour for similar tasks and occupations, compared to their hourly rate. Despite this limitation, it is most likely that gender differences in pay remain due to the Platform's role in shaping the interaction between work seekers and work providers: work seekers apply to jobs posted by work providers, after which the latter can review the applications and contact applicants for interviews, based on their profiles which include their hourly rates. ${ }^{67}$ At this point, some negotiation may go on between users and those in need of tasks performed, however the negotiation itself is not a structured element of the Platform's interface and may take place using another medium, such as email, chat, or telephone. ${ }^{68}$ There may be some negotiation regarding timeframe and expediency, and a move to a fixed rather than hourly rate. Such fixed rate will likely be derivative or connected to the posted hourly rate. While it is a possibility that during negotiation men's hourly rates will go down, and women's rates will increase, thus making the actual pay more equitable, it seems more likely that some gender discrepancy remains, especially in categories in which the difference in hourly rates is huge, such as the "Legal" category (women's average hourly rate is $63 \%$ lower than men's), or large such as "Accounting \& Consulting" (women's average hourly rate is $38 \%$ lower than men's), making it increasingly plausible that ultimately women are paid less for the same tasks. The gaps we found resonate with findings from studies on the pay gap in the general economy, further suggesting that the "gig" economy is not an anomaly to this pattern. ${ }^{69}$

${ }^{66}$ See Christine Exley, Muriel Niederle \& Lise Vesterlund, New Research: Women Who Don't Negotiate Might Have Good Reason, HARv. Bus. Rev. (Apr. 12, 2016), https://hbr.org/2016/04/women-who-dont-negotiate-their-salaries-might-have-agood-reason; Christine L. Exley, Muriel Niederle \& Lise Vesterlund, Knowing When to Ask: The Cost of Leaning-in (Harvard Bus. Sch., Working Paper No. 16-115, 2016), http:/ / www.hbs.edu/faculty/Publication\%20Files/16-115_a6680006-be03-44be-ab6f3625d3f21c00.pdf.

${ }^{67}$ See supra note 52.

68 Id.

${ }^{69}$ See supra note 26. 
While our computational approach to measuring differences between men and women in the "gig" economy through the data provided by the API of the studied platform limits our ability to measure actual pay, it allows for large data computation, and an actual snapshot of differences in the average hourly rates of men and women on the Platform. Furthermore, it uniquely captures some of the marketplace interactions that take place ahead of pay negotiations or actual pay in platform-facilitated labor. While survey data relies on answers to questions reported by men and women, our data set captures the shaping of new dynamics of self-evaluation and selfpresentation in the "gig" economy. Through these interactions, our findings suggest that we are witnessing the remaking of women into devalued laborers.

\section{PART III. THE INEPTITUDE OF CURRENT LEGAL NORMS}

Advances in technology are powerful tools that have influenced both industry and gender relations. ${ }^{70}$ As online platforms enhance widespread changes in labor, the law must adapt to the changing workplace. What can be done to ensure that women realize the promises of work in the "sharing" economy?

Law can provide at least two tools for enhancing gender equality in this context. First, online, platform-based labor should become an option that provides sustainable work for those heavily involved. This requires some labor protections like minimum wage, pro rata health insurance, and family leave, at least for those working a significant number of hours on platforms. This first tool will be discussed briefly in infra Part III.A as others have dealt with the question which it implicates: when workers should be considered employees. The second tool, addressed in infra Part III.B, focuses on the inability of antidiscrimination law to deal with women's platformlabor subordination. As our case study illustrates, there are dramatic gender disparities in hourly rates in platform-facilitated labor. While the case study does not purport to examine all platform-facilitated online labor, it should raise serious concerns about women's equality in this context, and about platforms' potential role in cultivating gender equality. Efforts to mitigate the perils faced disproportionately by women might include updating antidiscrimination laws to diminish gendered pay gaps or imagining entirely new forms of regulation.

70 Nancy B. Schess, Then and Now: How Technology Has Changed the Workplace, 30 Hofstra LAB. \& EMP. L.J. 435 (2013). 


\section{A. Employee Status}

The debate about labor protections directly implicates the question of whether taskers are employees or independent contractors. The law's answer to this question may vary according to the amount of control the given platform possesses over its taskers. ${ }^{71}$ If taskers are considered employees of a certain company, they become eligible for protective labor laws such as minimum wage and overtime. ${ }^{72}$ Online platforms, however, are fiercely resisting efforts to classify taskers as employees. ${ }^{73}$ Platforms insist that their workers are nothing more than independent contractors. ${ }^{74}$ Uber, for example, exerts considerable control over its drivers by setting rates and making termination decisions, ${ }^{75}$ yet considers them independent contractors. ${ }^{76}$ For workers on other platforms which do not set laborers' rates, it might be more difficult to argue for employee status. Yet even for such workers, considering all laborers on a given platform as business entities and micro-entrepreneurs ignores both the gatekeeping role such platforms have undertaken, and the surplus they attain for every transaction. Some have argued that we should view taskers' relationships to platforms as an intermediate status between traditional employment and independent contracting (proposing a third status of dependent contractors or independent workers). ${ }^{77}$ This approach would afford workers some labor protections, but not all. ${ }^{78}$

\section{B. Antidiscrimination}

Employment status is also critical to the second component, which focuses on gender in particular. The protections of antidiscrimination laws such as Title VII are triggered only in an

71 See supra note 19

72 See Sachs, supra note 7; Miriam A. Cherry, Beyond Misclassification: The Digital Transformation of Work, 37 COMP. LAB. L. \& POL'YJ. 577, 578, 581-82 (2016). See generally Cunningham-Parmeter, supra note 19.

73 See supra note 19.

74 This is clearly evident from platforms' terminology of laborers, see supra note 13, and see also the litigation in O'Connor v. Uber Techs., Inc., 58 F. Supp. 3d 989 (N.D. Cal. 2014); and Cotter v. Lyft, Inc., No. 13-CV-04065, 2016 WL 1394236 (N.D. Cal. Mar. 11, 2015).

${ }_{75}$ Cunningham-Parmeter, supra note 19, at 1, 11-13, 33-35.

76 Id.

77 Seth D. Harris \& Alan B. Krueger, A Proposal For Modernizing Labor Laws for Twenty-First-Century Work: The "Independent Worker", Hamilton Project (Dec. 2015), http://www.hamiltonproject.org/assets/files/modernizing_labor_laws_for_twenty_fi rst_century_work_krueger_harris.pdf.

$$
{ }^{78} I d \text {. }
$$


employment relationship. ${ }^{79}$ Even if workers do eventually win the battle over their employment status, antidiscrimination laws may require updating for the new, online economy. Since online labor is often performed under gender-blind policies, ${ }^{80}$ and without face-toface interaction, discriminatory treatment may be especially difficult to prove.

If, as some have argued, taskers should be viewed as dependent contractors or independent workers, ${ }^{81}$ antidiscrimination laws would apply, but other worker protections like health insurance mandates would not. ${ }^{82}$ Under this scenario, workers in this intermediate category would be significantly less protected than if they were deemed employees. Women might not be legally discriminated against, but all workers would still lack important supports. The lack of family leave may affect women more significantly than men. ${ }^{83}$ And, of course, intentional discrimination would remain difficult to prove. Still, an intermediate status may be better for workers than the status quo, in which workers are currently treated as independent contractors. ${ }^{84}$ Certain basic labor protections are not part of this relationship by operation of law, such as minimum wage and family leave, or even antidiscrimination laws such as Title VII (though some have long sought to amend antidiscrimination laws to cover independent contractors).$^{85}$

Yet even if online taskers are relegated to independent contractor status, one could argue that platforms still cannot permit discrimination to occur on their platforms. Scholars have recently claimed that some "sharing" economy companies, especially those offering services like housing or transportation, are "functional substitutes" for traditional public accommodations and therefore that federal public accommodation law should be updated to capture racial discrimination in the "sharing" economy ${ }^{86}$ Sex discrimination, on the

79 Pub. L. No. 88-352, tit. VII, 78 Stat. 241, 253-66 (1964) (codified as amended at 42 U.S.C. $\$ \S 2000$ e to $2000 \mathrm{e}-17$ (2012)).

${ }^{80}$ The Platform in our case study, for example, does not have a designated field for gender on its profile "template" but does have a field for name and photo.

Harris \& Krueger, supra note 77.

82 Id.

83 Women still perform the lion's share of family-work. See Schoenbaum, supra note 17 , at 3 .

84 Ross, supra note 33, at 1438-41.

${ }^{85}$ Lewis L. Maltby \& David C. Yamada, Beyond "Economic Realities": The Case for Amending Federal Employment Discrimination Laws to Include Independent Contractors, 38 B.C. L. Rev 239 (1997).

${ }^{86}$ Nancy Leong \& Aaron Belzer, The New Public Accommodations, 105 GEO. L.J. (forthcoming 2017), http://papers.ssrn.com/sol3/papers.cfm?abstract_id=2687486 
other hand, can be litigated under state public accommodation legislation, such as the Unruh Civil Rights Act in California. ${ }^{87}$ That Act bars sex discrimination by business establishments. ${ }^{88}$ If, as platforms claim, their laborers are business partners/micro-entrepreneurs/ independent contractors, then one could argue that platforms are business establishments that must treat clients (here, the taskers) without discrimination. ${ }^{89}$ Following the common law doctrine requiring places of public accommodation "to serve all customers on reasonable terms without discrimination and ... to provide the kind of product or service reasonably to be expected from their economic role," ${ }^{90}$ the Unruh Act forbids business establishments from engaging in sex discrimination in dealing with their clients. ${ }^{91}$

Similar laws can be found in other jurisdictions as well. ${ }^{92}$ Three doctrinal questions arise from this type of law, though: first, are online platforms business establishments under the Unruh Act? While most public accommodation doctrine has been interpreted to refer to physical accommodation, ${ }^{93}$ some precedents have extended Unruh's

(draft from July 23, 2016).

87 CAL. CIV. CODE $\$ \S 51-51.3$ (West 2016).

$88 \quad I d . \$ 51,51.5(\mathrm{a})$

89 See also Noah Zatz, Beyond Misclassification: Gig Economy Discrimination Outside Employment Law, ON LABOR (Jan. 19, 2016), https:/ /onlabor.org/2016/01/19/beyondmisclassification-gig-economy-discrimination-outside-employment-law.

90 In re Cox, 474 P.2d 992, 996 (Cal. 1970).

91 The Unruh Civil Rights Act, California Civil Code Section 51, provides, in pertinent part:

(b) All persons within the jurisdiction of this state are free and equal, and no matter what their sex, race, color, religion, ancestry, national origin, disability, medical condition, genetic information, marital status, sexual orientation, citizenship, primary language, or immigration status are entitled to the full and equal accommodations, advantages, facilities, privileges, or services in all business establishments of every kind whatsoever.

CAL. CIV. CODE $\$ 51$ (West 2016).

${ }_{92}$ See, e.g., Alberta Human Rights Act, R.S.A. 2000, c. A-25.5 (Can.); Treaty of Amsterdam Amending the Treaty on European Union, the Treaties Establishing the European Communities and Certain Related Acts art. XIII, Oct. 2, 1997, 1997 O.J. (C 340); Council Directive 2004/113, 2004 O.J. (L 373) 37 (EC) (implementing the principle of equal treatment between men and women in the access to and supply of goods and services); Isabelle Chopin \& Eirini-Maria Gounari, Developing AntiDiscrimination Law in Europe - The 27 EU Member States Compared, EuR. CommISSION 101 (Nov. 2009), https://ec.europa.eu/migrant-integration/librarydoc/developing-antidiscrimination-law-in-europe-the-27-eu-member-states-compared.

93 "Physical accommodation" refers to accommodations such as inns, hotels, restaurants, country clubs. Kelly Catherine Chapman, Gay Rights, the Bible, and Public Accommodations: An Empirical Approach to Religious Exemptions for Holdout States, 100 GEO. L.J. 1783, 1785-86 (2012). See, e.g., Koebke v. Bernardo Heights Country Club, 115 P.3d 1212 (Cal. 2005) (regarding country clubs). 
liability to websites when, for example, they denied access due to sexual orientation..$^{94}$

Second, are there legitimate business reasons (permissible under the statute) to allow taskers to offer their services at substantially different prices? From platforms' perspective, for example, this might generate more diverse profiles. Third, and most importantly, is the Unruh definition of discrimination too narrow? Under Unruh, cases have typically been concerned with assuring equal opportunity of access (whether to rental property or entrance to restaurants, country clubs, and other businesses)..$^{5}$ But in online labor, gender discrimination does not seem to appear in the form of formal barriers or overt exclusions: ${ }^{96}$ both men and women are free to participate as online taskers, yet pay inequality seems to occur in platform-facilitated labor. Under the Unruh Act, prohibiting this kind of disparity would require an interpretation that ensures not just equal access to platforms but prevents substantive discrimination from taking place within platforms. Courts have noted that the Unruh Civil Rights Act must be construed liberally. ${ }^{97}$ Still, some courts have required proof of intentional discrimination, ${ }^{98}$ an extremely difficult burden to satisfy in the online context.

94 See, e.g., Ashleigh Bergeron, Butler v. Adoption Media, LLC: Eradicating Sexual Orientation Discrimination in Cyberspace, 17 L. \& SeXuAliTy 173, 179-80 (2008) (examining Butler v. Adoption Media, LLC, 486 F. Supp. 2d 1022 (N.D. Cal. 2007), which declared that a website was a "business establishment" and its policy of allowing access only to heterosexual couples was not supported by legitimate business reasons).

${ }_{95}$ See Alison Rothi, Changing Ideas About Changing Diapers, 25 WHITTIER L. REv. 927 (2004) (discussing the Unruh Act).

${ }_{96}$ See, e.g., case study discussion supra Part II.

97 Munson v. Del Taco, Inc., 208 P.3d 623, 626 (Cal. 2009) (finding that liberal construction is necessary to carry out the Act's purpose to "create and preserve a nondiscriminatory environment . . . by 'banishing' or 'eradicating' arbitrary, invidious discrimination by such establishments. ... [The] Act 'serves as a preventive measure, without which it is recognized that businesses might fall into discriminatory practices"”) (citations omitted). The court holds that in the context of disability discrimination, a plaintiff proceeding under Section 51(f) of the Unruh Act "may obtain statutory damages on proof of an ADA access violation without the need to demonstrate additionally that the discrimination was intentional." $I d$. at 628 .

98 See Timothy B. Liebaert, The Death of the Unruh Civil Rights Act: An Examination of the Act After Harris v. Capital Growth Investors XIV and an Argument in Favor of Liberalizing the Act, 29 W. ST. U. L. REV. 1 (2001); Note, The Andiscrimination Principle in the Common Law, 102 HaRv. L. Rev. 1993 (1989). See, e.g., Greater L.A. Agency on Deafness, Inc., v. Cable News Network, Inc., 742 F.3d 414, 425 (2014) (holding that under the Unruh Act, plaintiffs must show intentional discrimination and affirmative misconduct on the part of those violating the Act-much more than disparate impact of a facially neutral policy); Koebke v. Bernardo Heights Country Club, 115 P.3d 1212 (Cal. 2005). 
Moreover, even if discrimination jurisprudence could be interpreted to resolve the doctrinal difficulties noted above, bringing claims under antidiscrimination law is not the only possible way, and may possibly not even be the best way, to tackle women's subordinate position in online labor. Indeed, filing such cases may generate publicity and have some "educational" effect on the market. But discrimination claims are largely based on private rights of enforcement which require that taskers' legal consciousness be raised ${ }^{99}$ and, once raised, that they would be capable and willing to present, and possibly litigate, claims. Since such claims are often filed individually, and after the fact, and given the magnitude and scale of online labor, their effect may be quite limited.

\section{PART IV. FROM DISCRIMINATION 3.0 TOWARDS EQUALITY-BY-DESIGN}

\section{A. A Third Generation of Discrimination}

The doctrinal difficulties regarding both federal antidiscrimination law and state public accommodation law, expose the ineptitude of current legal norms to address the devaluation of women's work in today's on-call, platform-facilitated economy. Of course, we are only beginning to understand the relationship between gender and the "gig" economy, and so this Part provides a nascent attempt to conceptualize gender inequality in this emerging context. In the past, plaintiffs in discrimination suits could point to a specific culprit, whether an individual or a policy, and the court would have to answer a basic underlying question: "Who did the discriminating?" In the first generation of sex discrimination claims, formal barriers played a significant evidentiary role. In the second generation, the quest was to identify underlying sex biases by a manager, company policy, or a workplace culture, dynamic, or organizational practice that lead to entrenching unequal access, exclusion, glass ceilings or harassment. ${ }^{100}$

But in today's world of platform work, as demonstrated in our case study, we are witnessing what may be a third generation of sex inequality-Discrimination 3.0. Our focus and the questions we ask must be adapted in two ways. First, the questions of access and inclusion should be supplemented with questions of usability. Men and women generally have equal access to the platform, yet the way

\footnotetext{
99 See Amy Blackstone et al., Legal Consciousness and Responses to Sexual Harassment, 43 LAW \& SOC'y REV. 631 (2009).

${ }^{100}$ See Susan Sturm, Second Generation Employment Discrimination: A Structural Approach, 101 Colum. L. Rev. 458, 465-74 (2001). Others have described the first phase of gender discrimination as ending exclusion and the second as transforming male centred norms, see Abrams, supra note 28, at 1186.
} 
they may be able to benefit from platform-facilitated labor seems to vary. Second, the goal should increasingly shift from aiming to determine who is doing the discrimination to answering how the discrimination is being effectuated. Indeed, the how question has been suggested by antidiscrimination scholars in other contexts, ${ }^{101}$ but it is increasingly important in the online labor arena, where intentional discrimination, and even biases towards an individual tasker, are often virtually impossible to prove. We should therefore increasingly be asking how inequality is being (re)produced and in which institutionalized ways is discrimination enabled by platforms, and by society? We should steadily be inquiring how discrimination is facilitated and harbored by the practices of platform-facilitated on-call labor. But also, consider the structural disadvantages with which laborers come to use "gig" economy platforms to begin with. ${ }^{102}$

As for platforms, we know that they not only represent social interactions, but that the way platforms are structured-their architecture, meaning their technological affordances and codeaffects human behavior. ${ }^{103}$ Platform codes are invisible to most of us, yet they operate as de facto law in the online arena. ${ }^{104}$ The way they regulate is a function of their algorithmic design. ${ }^{105}$

In our case study, we revealed consistent gender discrepancies regarding hourly rates. But women were not excluded from the Platform, which could be considered prohibited intentional discrimination, and the Platform may not have even portrayed them in a biased or sex-stereotyped manner. In fact, on its face, its interface is gender agnostic, in the sense that it does not structure gender as an official field in the user's profile. One may argue that the platform

101 Sturm, supra note 100, at 460-61. See also Martha Albertson Fineman, The Vulnerable Subject: Anchoring Equality in the Human Condition, 20 YALE J.L. \& FEMINISM 1 (2008) (arguing that we should move from focusing on individual discrimination focused on identity and look at the ways social institutions distribute power and resources).

102 For example, structural disadvantages include gendered pay gaps in the offline labor market and lack of paid family leave. See supra note 26; see also Maxine Eichner, Square Peg in a Round Hole: Parenting Policies and Liberal Theory, 59 OHIO ST. L.J. 133, 148-50 (claiming that U.S. parental leave policy fails to protect a sufficient concept of parenting); Laura T. Kessler, Keeping Discrimination Theory Front and Center in the Discourse over Work and Family Conflict, 34 PEPP. L. REv. 313, 314 (2007) (explaining connections between gender bias and work/family conflict).

103 Lawrence Lessing, Code Version 2.0 5-6, 24, 34 (2006); see also Joel R. Reidenberg, Lex Informatica: The Formulation of Information Policy Rules Through Technology, 76 Tex. L. REv. 553, 555 (1998); Lawrence Lessig, The Law of the Horse: What Cyberlaw Might Teach, 113 Harv. L. REV. 501, 505-06 (1999).

104 LESSING, supra note 103, at 58.

105 Id. 
solely reflects age-old social dynamics. Yet the codes of a platform may nonetheless condition some of the social interactions it hosts. ${ }^{106}$ Contemplating the ties between platforms' policies, their technological affordances and user behavior, along with opportunities in play outside of the platform in the market and in the family, may explain some of the discriminatory effect we observed. ${ }^{107}$ These interactions, taken together with women's structural disadvantages in the labor market and the family more generally suggest that platformfacilitated labor should be viewed cautiously as a liberating, equalityenhancing work option for women.

\section{B. Towards A Platform for Equality?}

The aim of this last subsection is to briefly sketch a possible direction for enhancing equality in platform-facilitated labor in the future. If "sharing" economy companies are made aware of the discrimination taking place on their platforms, they may be inclined to consider ways to offset inequality. Changes within a platform's design may prove necessary to prevent today's forms of sex discrimination at work, and regulating platforms through law and technology may advance women's economic equality in online workplaces. Yet, it may not be quite as straightforward as merely embedding the value of equality into a technology and then expecting it to create a direct positive effect on society. ${ }^{108}$ There may well be unintended consequences to this move or indeterminate ramifications which we

106 On the role of the technological affordances of social media platforms in shaping discrimination, see Anat Ben-David \& Ariadna Matamoros Fernandez, Hate Speech and Covert Discrimination on Social Media: Monitoring the Facebook Pages of ExtremeRight Political Parties in Spain, 10 INT'L J. OF CoMm. 1 (2016).

107 When further thinking about how discrimination may be facilitated through platforms regarding the mediation of the work related social interactions and the hourly rate gap, we should be thinking about platforms' existing features and affordances, but also consider those features that are absent from the interface. Consider the following two examples. First, the negotiation process mentioned above. In most cases, the negotiation on the terms of actual pay that incorporates a social interaction between the work-seeker and the work-provider takes place outside of the Platform. Such practice of posting hourly rates that are pending negotiation, along with the distancing of the negotiations from the Platform, may contribute to the preservation of age-old gender dynamics in the labor market. Second, the Platform's design to conduct feedback scores without substantive guidelines may also cause those more in need of such work to a-priori lower rates to receive a better feedback score.

108 Mary Flanagan, Daniel C. Howe \& Helen Nissenbaum, Embodying Values in Technology: Theory and Practice, in INFORMATION TECHNOLOGY AND MORAL PHILOSOPHY 322-23 (Jeroen van den Hoven \& John Weckert eds., 2008). See also Helen Nissenbaum, From Preemption to Circumvention: If Technology Regulates, Why Do We Need Regulation (and Vice Versa)?, 26 Berkeley TeCH. L.J. 1370 (2011) ("[I]f we have technology, why do we need law?"). 
cannot anticipate. However, given that technology is already functioning as regulation, those who care about gender equality must consider ways to support the de-facilitation of platform inequality. Since platforms have the best access to large-scale information about their workers' hourly rates and pay, as well as control over membership, shaping of profile categories, feedback scores, and whether to allow for negotiations, platforms themselves could best be suited to enact pre-emptive measures through their affordances and codes to de-facilitate and counteract discrimination. ${ }^{109}$ "Sharing" economy companies could promote within their architecture an "Equality-by-Design" (EbD): the structuring of platforms in a manner that is sensitive to prevailing forms of gender discrimination, in ways that extend beyond merely omitting gender as a formal element of platforms' template for profiles or not portraying women in a biased manner.

This goal of EbD could be affected through measures platform designers, researchers and policy makers should start to imagine, contemplate and discuss. These could include, for example, having platforms inform the market of average hourly rates by providing notices of average hourly rates for certain tasks to taskers, or publishing reasonable hourly rates, or suggesting hourly rates to users. Platforms may also reflect on the ways profiles are displayed and how the application system might enable discrimination, or on providing transparent guidelines for assessing users' performance and, importantly, on whether negotiations should be structured or narrowed. Such changes, if put in place, could be quite easily monitored by platforms' technologies, and verified and evaluated for their equality-enhancing capacities. ${ }^{110}$

In fact, such mechanisms and reflections could be self-imposed and self-regulated by platforms. ${ }^{111}$ It is fair to assume that companies

109 See Katharine T. Bartlett \& G. Mitu Gulati, Discrimination by Costumers (Duke L. Sch. Pub. L. \& Legal Theory Series, No. 2015-4, 2016), http://papers.ssrn.com/sol3/ papers.cfm?abstract_id=2540334. With regard to sexual harassment law, see Mary Anne Franks, Sexual Harassment 2.0, 71 MD. L. ReV. 655 (2012).

110 See Flanagan, Howe \& Nissenbaum, supra note 108, at 344. For the dangers associated with algorithmic regulation, see, for example, Maayan Perel \& Niva ElkinKoren, Black Box Tinkering: Beyond Transparency in Algorithmic Enforcement, FLA. L. REV. (forthcoming), http:// papers.ssrn.com/sol3/papers.cfm?abstract_id=2741513.

111 Some sharing economy companies have begun to prohibit posting materials that bans users based on sexual orientation. Nick Duffy, Accommodation website Airbnb removes listing that banned gay couples, PINkNews (Nov. 23, 2014, 11:52 AM), http://www.pinknews.co.uk/2014/11/23/accomodation-website-airbnb-removeslisting-that-banned-gay-couples. For an example of effective self-regulation in the general economy, see Sturm, supra note 100, at 509-19. 
aiming to attract women laborers would be well advised to consider such mechanisms. However, imposition of legal liability might ultimately be necessary to initiate some of these reforms.

\section{CONCLUSION}

This Article aims to ignite a conversation about equality in the "sharing" or "gig" economy. It draws attention to the gender inequality taking hold within digital platforms. It empirically shows that gender inequality is re-configured and reproduced through platformfacilitated labor, casting doubt on the liberating and equalityenhancing promise platform-facilitated labor carries for women. Looking ahead towards the legal and policy choices that are likely to take place in the near future regarding labor in the "sharing" economy, the realization that gender inequality is reproduced on platforms must force us to begin to contemplate legal, social and technological mechanisms to mitigate this phenomenon. 